Review

\title{
Can conventional clinical chemistry tests help doctors in the monitoring of oncology patients?
}

\author{
Valery G. Zaitsev ${ }^{1}$, Anastasia A. Zheltova ${ }^{2}$, Svetlana A. Martynova ${ }^{3}$, Elena V. Tibirkova ${ }^{2}$ \\ ${ }^{1}$ Volgograd State University, Volgograd, Russia \\ ${ }^{2}$ Volgograd State Medical University, Volgograd, Russia \\ ${ }^{3}$ Volgograd Regional Clinical Oncological Dispensary, Volgograd, Russia
}

Received 15 January 2020, Revised 6 May 2020, Accepted 27 May 2020

(C) 2020, Zaitsev V.G., Zheltova A.A., Martynova S.A., Tibirkova E.V.

(C) 2020, Russian Open Medical Journal

Abstract: The use of laboratory assays in the diagnostic care of oncology patients can markedly increase the efficacy of cancer treatments. Many cancer-specific biomarker assays have been developed. However, the use of these has some limitations due to their cost. Moreover, not every diagnostic laboratory can perform a complete set of these assays. On the other hand, the smart use of conventional clinical chemistry tests could improve the management of cancer. They could be especially valuable tools in the long-term care of patients with a verified diagnosis. In this review, we discuss the utilization of the conventional clinical chemistry assays for the diagnosis, monitoring and prognosis of various oncological diseases. The use of conventional blood tests to assess the levels of chemical elements, metabolites and proteins (including enzymatic activity measurements) in the care of oncology patients is discussed. We have shown that some clinical chemistry assays could be used in the management of distinct kinds of cancer.

Keywords: clinical chemistry; cancer biomarkers; oncology; disease prognosis; monitoring

Cite as Zaitsev VG, Zheltova AA, Martynova SA, Tibirkova EV. Can conventional clinical chemistry tests help doctors in the monitoring of oncology patients? Russian Open Medical Journal 2021; 10: e0103.

Correspondence to Valery G. Zaitsev. Address: Department of Bioengineering and Bioinformatics, Volgograd State University, 100 Universitetskii prospect, Volgograd 400062, Russia. Phone: +78442460806. E-mail: valeryzaitsev@gmail.com.

\section{Introduction}

Cancer is one of the leading causes of mortality worldwide. Moreover, the numbers of newly diagnosed cancer cases are twice that of annual cancer mortality rates [1]. The effectiveness of cancer treatment significantly depends on early diagnosis and on the precise verification of a cancer type. There are several approaches to cancer diagnostics. These include various types of instrumental and laboratory diagnostics. Cytomorphologic analysis, flow cytometry [2], circulating tumour cells detection [3, $4]$, molecular-genetic methods $[5,6]$ and detection of specific tumour biomarkers $[7,8]$ are widely used for the laboratory diagnosis of cancer. After diagnosis verification, diagnostic techniques could be used to monitor the effectiveness of treatment and to achieve stable remission. Another important purpose of laboratory diagnosis is to predict the course of the disease (i.e., the risk of mortality) and the development of complications, and to monitor the patient's condition after remission for early detection of cancer recurrence. Laboratory monitoring and prognosis could be performed by specific tumour biomarker assays $[8,9]$. The disadvantage of the tumour-specific tests is the relatively high cost. Additionally, not every diagnostic laboratory can perform a complete set of these assays.

On the other hand, tumour development causes marked alterations in body metabolism, hence, cancer can be associated with abnormal results in some clinical chemistry tests. Although conventional clinical chemistry tests have insufficient sensitivity and specificity for cancer diagnosis they can be used in the monitoring and prognosis of a patient's state if an oncological diagnosis has been verified. As conventional clinical chemistry tests are widely available and inexpensive, they can help the physician in the care of cancer patients, especially in developing countries.

In this review, we have set out to summarize current knowledge about the opportunities of the conventional biochemical test's use in oncological clinical practice.

\section{Routine clinical chemistry tests in cancer care}

Routine clinical chemistry tests have limited use in the management of oncological patients due to the relatively low specificity and selectivity in the diagnosis of cancer. On the other hand, metabolism alterations associated with tumour development or cancer complications can influence the results of conventional clinical chemistry blood tests. Hence conventional laboratory assays could be applied to assess the severity of disease or its complications. Further normalization of these routine laboratory tests during cancer treatment can be used to monitor the success of therapy. Availability, low cost and low labour intensity of conventional biochemical tests can reduce costs and improve the efficiency of monitoring the effectiveness of therapy compared to the measurement of tumour markers or the use of cytological methods. In the following, we present combined data about the state of the art for conventional clinical chemistry tests 
used in predicting changes in the course of cancer development and monitoring the effectivity of treatment.

\section{Assays of elements}

\section{Calcium}

Alterations of calcium metabolism are common metabolic disorders in the tumour process. Moreover, untreated hypercalcaemia or hypocalcaemia can be dangerous for patients with cancer. Accordingly, the determination of calcium content in blood plasma/serum should be recommended to all patients with neoplasms. The determination of total calcium, adjusted for serum albumin, is considered to be more appropriate in cancer patients than the determination of ionized calcium. It should be noted that hypercalcaemia in cancer patients is found more frequently than hypocalcaemia [10].

Hypercalcaemia is a reasonably common condition in patients with neoplastic processes and occurs in $5-30 \%$ of cases, but its prevalence has been progressively decreasing in recent years due to earlier and more effective treatment [10-13]. The most evident causes of hypercalcaemia are associated with osteolytic bone primary tumour metastases $[12,14]$. Hypercalcaemia can develop due to the production of parathyroid hormone (PTH) or similar proteins by the tumour [12]. Other causes of hypercalcaemia are disorders of urine calcium excretion due to kidney tumour development or dehydration, often associated with cancer. Another non-specific cause of hypercalcaemia is an alteration of bone metabolism as a result of the cancer patient's low motor activity. In addition to osteolytic bone tumours hypercalcaemia is most often associated with tumours of lung, breast, head and neck, gastrointestinal tract, kidneys, as well as myelo- and lymphoproliferative diseases $[10,11,13,15]$. However, in $31 \%$ of hospitalized cancer patients, hypercalcaemia development is not related to tumours [16]. Measurement of the total calcium concentration in the blood serum in combination with phosphorus, creatinine, PTH, PTH-like peptide and various forms of vitamin $\mathrm{D}$ should be recommended to accurately determine the cause of hypercalcaemia $[12,15,17]$.

The detection of hypercalcaemia is most important in cases of primary osteogenic tumours or metastases in bone tissue since the degree of increase in calcium concentration can be correlated with the scale of lesion or tumour growth rate. The effect of inhibition of bone resorption in antitumour treatment can be estimated by the rate of normalization of calcium concentration in the blood serum $[12,17]$. The increased calcium content of the serum at the time of non-bone cancer diagnosis is associated with a high risk of subsequent detection of bone metastases [18-20]. In various types of solid tumours, hypercalcaemia is a poor prognostic feature associated with a short survival period, especially when combined with a low serum albumin content [21-24]. Suitable treatment of the cancer-associated hypercalcaemia can significantly increase median survival time, for example, from 106 to 432 days in gynaecological cancer patients [25]. Jin et al. noted that development of the cancer-associated PTH-mediated hypercalcaemia within 70 days after a cancer diagnosis significantly increased the risk of shorter survival time in both solid tumour and haematological cancers [26].

Hypocalcaemia occurs in more than $10 \%$ of hospitalized cancer patients, with prevalence varying from 1.6 to $13 \%$ in different groups of cancer patients [27] and even to $30 \%$ in patients with advanced prostate cancer [10]. According to Schattner et al. there are 12 mechanisms that can lead to a decrease in the total calcium content in the serum of patients with malignant tumours [27]. When hypocalcaemia is detected, it is necessary to differentiate between true hypocalcaemia and pseudohypocalcaemia that occurs as a result of reduced serum albumin content, which is often observed in cancer patients [28]. A very rare cause of pseudohypocalcaemia is the impact on the results of calcium determination on some paramagnetic contrast agents for magnetic resonance tomography [29, 30]. True hypocalcaemia can be observed both at normal or low concentrations of PTH in the blood serum and at its elevated content. One of the causes of hypocalcaemia is a magnesium deficiency that causes resistance of cells to the action of PTH with subsequent violation of PTH secretion by parathyroid glands. Another reason is the destruction of parathyroid glands tissue (or their removal) with the development of partial or complete PTH deficiency in the body. In tumour processes, a combination of hypocalcaemia with elevated PTH level in the blood serum as a result of secondary hyperparathyroidism is more often observed. In this situation, the causes of hypocalcaemia are ectopic production of calcitonin by tumours, vitamin D deficiency, calcium malabsorption due to the development of tumours or acute pancreatitis (which can occur as a response to prior hypercalcaemia), excessive deposition of calcium in osteoblastic metastases or as a consequence of acute hyperphosphatemia (which usually occurs with massive destruction of cells, including tumour lysis syndrome), or excessive calcium secretion due to disorders of kidney function [27]. A decrease in the level of circulating calcium may also occur due to the use of some anticancer drugs or bone resorption inhibitors [10, 31, 32].

The prognostic value of hypocalcaemia in cancer has not been systematically investigated, but apparently can significantly depend on the cause of its occurrence. In many cases, hypocalcaemia is transient and asymptomatic or with mild symptoms. Hypocalcaemia may have prognostic value in patients with acute and urgent conditions and in monitoring the effectiveness of tumour treatment. Hypocalcaemia has important diagnostic and prognostic value in osteoblastic metastases of tumours in bone tissue [33, 34]. To identify the cause of hypocalcaemia in cancer, it is recommended to use a complex of conventional biochemical tests, including the determination of total serum calcium, magnesium, PTH, creatinine, phosphate, liver enzymes, amylase and 25-hydroxide vitamin D [27].

\section{Phosphorus (Phosphate)}

Changes in the content of serum phosphorus (in the form of inorganic phosphates) occur in cancer patients much less often than hypercalcaemia or hypocalcaemia. However, hypo- or hyperphosphatemia can often threaten a patient's life. Osteolytic bone tumours (primary and metastases) and onco-hematologic diseases (e.g. multiple myeloma) may be accompanied by hyperphosphatemia [35]. An increase in serum phosphorus level can be observed as a result of tumour treatment [36-38]. A significant increase in serum phosphorus after tumour removal is a poor prognostic factor for patient survival [38]. Often, hyperphosphatemia is a typical sign of tumour lysis syndrome [3942] and was proposed as one of the criteria of the laboratory tumour lysis syndrome diagnosis [43]. Since the development of tumour lysis syndrome threatens the patient's life due to the possible development of complications (acute renal failure, cardiac 
arrhythmia, convulsions, and multiple organ damage), the presence and severity of hyperphosphatemia (along with the content of creatinine and uric acid) can be an important prognostic factor [42, 44, 45]. Moreover, the elevation of serum phosphate concentration higher than its upper normal limit (UNL) can transform an intermediate ( $1 \%$ to $5 \%$ ) risk of tumour lysis syndrome development into a high (greater than 5\%) risk in various lymphoproliferative disorders [41]. Hyperphosphatemia is a poor survival prognostic factor after surgical removal of colorectal tumours [38]. Detection of hyperphosphatemia is important for determining the cause of tumour-associated hypocalcaemia [27].

The reduction of serum phosphorus associated with the development of tumours is quite rare, and can be associated with the paraneoplastic syndrome of tumour-induced osteomalacia, leading to increased renal phosphate excretion [46-49], with the development of osteoblastic metastasis in bone tissue [50-52], and is also sometimes observed in lymphoproliferative diseases [53]. Some anti-cancer drugs can lead to a reduced phosphorus level in the blood serum [54].

\section{Iron}

Oncological diseases are often accompanied by the development of anaemia (prevalence up to $64 \%$ among cancer patients), while in many cases it is secondary to iron deficiency $[55,56]$. The main mechanism of development is the increased production of interleukin (IL)-6, which activates the secretion of hepcidin. This leads to the retention of iron in the depot and suppression of its release into the bloodstream. At the same time, there is a higher degree of transferrin serum iron saturation [55, $57,58]$. Therefore, the determination of the level of latent ironbinding capacity or ferritin concentration is a more accurate indicator of iron deficiency in cancer than the content of iron in the blood serum [58-61].

\section{Assays of metabolites \\ Glucose}

Glucose determination is one of the most widely used biochemical tests. In oncology, it is used to detect hypoglycemia, which often accompanies the tumour process. Several factors can lead to a decrease in blood glucose level. First is the ability of some tumours to secrete insulin or other carbohydrate metabolism regulators: glucagon-like peptide, insulin-like growth factors and somatostatin. They are tumours originating from the islet cells or cells of APUD-system (e.g., stromal tumours of the gastrointestinal tract). Another cause of hypoglycemia is high glucose consumption by large, aggressive or rapidly growing tumours. Therefore, the normalization of glucose level during treatment can serve as a good criterion for therapy effectiveness [45, 62]. Blood plasma/serum glucose concentration can be used to predict remission period and overall survival in some kinds of cancer [6367].

\section{Uric acid}

The determination of uric acid content is another routine analysis that can be useful in monitoring the progression of cancer and making decisions about treatment. Approximately $20 \%$ of patients with lympho- and myeloproliferative diseases have hyperuricemia. Excess production of uric acid is associated with extremely rapid production and destruction of blood cells and hypermetabolism syndrome [68]. Severe hyperuricemia is observed as a result of tumour lysis [69], which allows the use of the uric acid levels in the blood serum to assess the risk of tumour lysis syndrome $[41,70,71]$, and for the monitoring of the patient's life-threatening condition [42, 45]. In colorectal tumours, hyperuricemia is an indicator of the risk of cancer-associated metabolic syndrome [72], and the normalization of uric acid level can be used in the monitoring of therapy effectiveness [73].

\section{Bilirubin}

A recent study has shown that an elevated level of total serum bilirubin in intrahepatic cholangiocarcinoma is an independent predictor of negative prognosis [74]. However, higher bilirubin content is a factor indicating a reduced risk of patient's death in various types of cancer [75, 76] and a protective factor for colorectal cancer $[77,78]$. Elevated levels of total bilirubin in the serum also can play a protective role in non-liver cancers [79]. Higher direct bilirubin concentrations have been shown as a predictor of lymph node metastasis in rectal cancer [80].

\section{Creatinine}

Elevated concentration of creatinine is a strong predictor of tumour lysis syndrome development in patients with haematological malignancies [71] and is recommended to use in the grading of clinical tumour lysis syndrome [43].

\section{Assays of enzymes \\ Hepatic enzymes}

Among the usual biochemical tests based on determining the activity of enzymes in blood serum or plasma, a special place belongs to the so-called hepatic enzymes. It is well known that increased activity of enzymes such as alanine aminotransferase (ALT), aspartate transferase (AST), gamma-glutamyl transferase (GGT) and alkaline phosphatase (ALP) is observed in the destruction of liver parenchyma cells, regardless of their cause [81]. Therefore, an increase in the level of hepatic enzymes in an established oncological diagnosis will serve as an indicator of the degree of liver damage. Accordingly, a decrease in the activity of these enzymes during treatment will indicate its effectiveness. The same indicators are important for the prognosis of the disease. Thus, an increase in the activity of any aminotransferase above 80 $U / L$, especially with hypoalbuminemia indicates a high death risk of patients with tumours at late stages of development [82]. Adverse prognostic factors in the survival of patients with intrahepatic cholangiocarcinoma are increased activities of GGT and ALP [74].

\section{Alkaline phosphatase}

Alkaline phosphatase (ALP) is a body-wide expressed enzyme. As ALP is essentially involved in bone formation and secreted by osteoblasts [83], determination of its activity is widely used in laboratory diagnostics of bone tumours [84]. Although this test is often used to detect metastases of other bone tumours $[85,86]$, its prognostic value is relatively low [87], and the positive test result is associated primarily with osteoblastic metastases [84]. A comparison of patients with osteosarcoma and patients with other lesions of bone tissue showed that the determination of ALP 
activity has a high specificity (about 90\%) in the detection of primary osteogenic sarcoma, but the sensitivity of this test was relatively small (about 53\%). ALP activity in the serum is linearly correlated with tumour size [88].

The relatively low specificity of ALP activity determination in other tumour processes in bone tissue is associated with peculiarities of this enzyme biology. There are four ALP isoforms in the human body: tissue-non-specific (encoding by ALPL gene), intestinal (encoding by ALPI gene), placental (encoding by ALPP gene), and placental-like (encoding by ALPPL2 gene). The last three isoforms are closely homological to each other, and their expression is specific to particular tissues. Tissue-non-specific ALP is expressed in different organs, mainly in liver, bone and kidney [83]. Therefore, an increase in the total ALP activity in blood serum/plasma can occur due to the release of the enzyme from almost any tissue. In particular, the increase in the ALP activity in blood serum may be due to the lesions of liver tissue mentioned above. Moreover, tests to determine bone-specific ALP also do not differentiate enzyme molecules originating from bone, liver, kidney or, for example, nervous tissue. Improved diagnosis of tumours using the ALP assay is possible by combination with other biomarkers, for example, metalloproteinase MMP-9 [89] or determination of tissue-specific ALP isoforms [90]. However, such tests are not commonly used in laboratory medicine.

At the same time, the determination of total ALP activity can be used as a biomarker for monitoring or in the prognosis of patients with an already verified cancer pathology. The high serum ALP activity in bone metastases of various tumours is correlated with shorter survival of patients [91]. Moreover, if the activity of ALP exceeds a certain critical level (non-equal for various types of cancer) at the time of initial cancer diagnosis, this may indicate a high risk of metastasis in bone tissue even if specific tumour biomarkers have no predictive significance $[18,20,92-94]$. Diagnostic accuracy of bone metastases prediction can be improved by the use of a combination of the useful laboratory tests: ALP + calcium + hemoglobin in bladder cancer [20] and in renal cancer [93]; ALP + the prostate-specific antigen (PSA) $[92,95]$ or ALP + PSA + tartrate-resistant acid phosphatase in prostate cancer [96]. The high activity of ALP in the blood serum is associated with poor survival prognosis and a high risk of metastasis in patients with osteosarcoma $[88,97]$. The specificity of osteosarcoma metastases prediction during the next 3 years is $90 \%$ with a sensitivity of about $53 \%$. The decrease in the ALP activity during treatment of osteosarcoma may serve as an indicator of the treatment effectiveness [88]. On the other hand, some studies found no relation between bone metastases formation and elevated serum ALP activity [98].

Serum ALP activity was shown to predict overall survival rates of prostate cancer patients during docetaxel treatment (especially in combination with PSA and C-reactive protein levels) and the safety of longer docetaxel therapy (better in combination with haemoglobin concentration) [98]. ALP was also proposed as a biomarker to differentiate transient PSA rise after the initiation of chemotherapy (PSA flare) from early progressive PSA elevation in prostate cancer patients with bone metastasis. Absence of elevation of ALP during the first cycle of docetaxel chemotherapy in patients with castrate-resistant prostate cancer was closely associated with transient PSA flare [100].

Additionally, ALP determination has specific significance in some cases of cancer-associated hypercalcaemia. Patients with lung cancer-associated hypercalcaemia had a poorer survival prognosis in the case of normal ALP levels compared to patients who had elevated ALP levels [24].

\section{Acid phosphatase}

Human acid phosphatase (ACP) has more isoforms than the ALP [101]. In the laboratory diagnosis of cancer, the most important isoforms are prostatic acid phosphatase (PAP or PACP, encoded by ACP3 gene) and tartrate-resistant acid phosphatase (TRACP, encoded by ACP5 gene).

PACP has historically been the first biomarker used in prostate cancer diagnosis since the 1940s. With the introduction into clinical practice of the PSA test, application of PACP assay in the diagnosis of prostate cancer gradually subsided due to its low sensitivity, especially in the early stages $[102,103]$. Although intracellular and secretory PACP in large quantities is synthesized in normal and transformed epithelial cells of the prostate gland [103], in highly differentiated tumours the synthesis of this enzyme is reduced $[103,104]$. In extra-prostatic cells, PACP is synthesized mainly in the form of a transmembrane variant (alternative splicing product), and the synthesis of cytosolic variant is insignificant or absent [104]. Importantly, tumours localized not only in the prostate gland can synthesize and secrete PACP [103]. All these facts caused a decrease of interest in the use of PACP for the diagnosis of prostate cancer. However, in recent years, PACP assay has again been used as a diagnostic and monitoring test: to predict the risk of relapse after surgery or radiotherapy and to predict survival [102] and to estimate the risk of bone metastases [96]. It was shown that the metastases of prostate tumours in bone tissue express PACP [105] regardless of whether the metastases are osteoblast or osteoclast [106]. Subsequent studies may be able to evaluate the significance of PACP assay in the prognosis and monitoring of metastatic prostate cancer.

TRACP is an isoform of acid phosphatase, which is easily enzymologically identified because TRACP activity is not inhibited by L-tartrate. This enzyme can be synthesized in two variants, denoted as isoforms $5 a$ (TRACP-5a) and $5 b$ (TRACP-5b). TRACP expression is detected in various cell types including osteoclasts, neurons, adipocytes and activated macrophages [107]. Activated osteoclasts synthesize and secrete large amounts of TRACP, so the determination of the activity or amount of this enzyme has long been widely used in the diagnosis of various bone lesions, including primary tumours and bone metastases [84, 96, 108]. However, the increase in the activity of TRACP in the blood serum can also be observed in non-oncological diseases, such as obesity [109] or rheumatoid arthritis [110]. Because isoform 5b is specific to osteoclasts, but not to other types of human cells $[84,111]$, it is recommended to use the definition of TRACP-5b for a more accurate diagnosis of bone metastases [84, 87, 91]. However, for prognostic purposes and to monitor treatment response in patients with an established diagnosis it is sufficient only to assess total levels of serum TRACP activity [108]. Determination of the activities of TRACP and ALP allows detecting and monitoring of both osteoclastic and osteoblastic bone tumours [96].

\section{Lactate dehydrogenase}

Data about the prognostic significance of increased serum activity of lactate dehydrogenase (LDH) are contradictory. Some studies found an association of elevated LDH activity with a very poor prognosis $[76,112]$ but other studies did not $[22,75,99$, 
113]. A meta-analysis of 76 studies showed increased LDH levels (median cut-off $245 \mathrm{U} / \mathrm{L}$ ) were associated with increased risk of shorter survival time especially in renal cell, melanoma, gastric, prostate, nasopharyngeal and lung cancers [114]. In various lymphoproliferative disorders LDH activity (cut-off is $2 \times U N L$ ) is used to differentiate low, intermediate and high risk of tumour lysis syndrome development $[41,69]$. Serum LDH activity higher than $500 \mathrm{U} / \mathrm{L}$ was strongly associated with developed tumour lysis syndrome in pediatric patients with Burkitt's lymphoma or B-cell acute lymphoblastic leukaemia [115]. Many studies identified high LDH activity as an independent risk factor for tumour lysis syndrome $[44,70,71,116]$.

\section{Assays of non-enzymatic proteins \\ Acute phase proteins}

Acute phase proteins (APPs) are blood plasma proteins whose concentration can change during inflammation response development. Synthesis and secretion of APPs by hepatocytes and some extrahepatic cells are regulated by proinflammatory cytokines such as IL-1, IL-2 and tumour necrosis factor- $\alpha$ (TNF $\alpha$ ). One of the most important and well-known APPs is C-reactive protein (CRP) $[117,118]$.

The increase in the content of positive proteins of the acute phase of inflammation is observed in tumours of various types. Theoretically, changes in these indicators can be used to monitor the course and treatment effectiveness in various types of extrahepatic cancer [117]. It is known that APPs as biomarkers usually have high sensitivity (but low specificity) [118]. However, a small number of large clinical trials have been conducted. An especially important indicator today is the content of C3 and C4 complement proteins. This is due to the peculiarities of the relationship between the complement system and the tumour process. Complement activation often stimulates tumour growth, causing tumour cells dedifferentiation. This can increase cancer's aggressiveness as well as promote metastasis. Moreover, some tumour cells secrete several complement proteins, as well as expressing on their surface anaphylatoxin receptors involved in the activation of tumour growth. Thus, the determination of C4 and - especially - C3 proteins levels can serve as an indicator of aggressiveness and metastatic activity of tumours [119, 120,121]. Other APPs can also be used to predict the progression of tumour growth and metastasis, to assess the risk of death, and to monitor the effectiveness of treatment. Thus, the level of haptoglobin can be used to predict the rate of progression and the risk of tumour metastasis [122-124]. Determination of $\alpha 1$-antitrypsin in the blood serum is a good indicator for monitoring the effectiveness of anticancer therapy $[125,126]$. The increase in CRP level in cancer patients is independently associated with a decline in quality of life (for women with breast cancer) [127], increased risk of cancerrelated mortality (for men with lung cancer) [128], elevated lethality (for patients with gastric cancer after gastrectomy) [61] and poor overall survival during docetaxel treatment of patients with prostate cancer [99].

\section{Beta-2-microglobulin}

Another often recommended analysis for cancer patients is the determination of $\beta 2$-microglobulin. Its increased content is observed in carcinomas, solid tumours of lungs, kidneys, prostate, breast, lympho- and myeloproliferative diseases. This protein is associated with stimulation of various tumour growths, so its increase can serve as a good indicator for assessing the rate of tumour progression, and the normalization of its content will be a criterion for the treatment effectiveness $[129,130]$.

\section{Serum albumin}

Hypoalbuminemia can accompany a variety of cancers. In patients with tumours in the late stages of development, hypoalbuminemia is a strong negative predictor: a decrease in serum albumin content below $30 \mathrm{~g} / \mathrm{L}$ is associated with a twofold increase in the risk of death of a patient in the next six months [82]. The decrease in albumin level in colorectal tumours, prostate cancer, breast cancer, liver tumours also indicates an unfavourable medium-term prognosis $[74,76,131,132]$. Hypoalbuminemia is a predictor of poor survival in cancer-associated hypercalcaemia [21, $22,133-135]$. At the same time, it should be remembered that in cancer patients, the development of hypoalbuminemia may be associated not only with impaired liver function or changes in the distribution of albumin in the body but also with the development of complications of the underlying disease, for example, chronic renal failure.

\section{Proteins associated with the thyroid gland}

Two indicators related to the function of thyroid gland can be used for the differential diagnosis of thyroid carcinoma. This possibility is based on the increase in the content of calcitonin in most patients with medullary carcinoma (it is preferable to conduct the test with stimulation) [136] and increased serum level of thyroglobulin in patients with other types of thyroid carcinoma [137].

\section{Summary}

Appendix 1 summarises data from the research publications estimating the significance of routine blood serum/plasma clinical chemistry tests in cancer patient care.

\section{Conclusion}

The modern clinical diagnostic laboratory has a large set of diagnostic tests; however, their potential is not fully used. Even routine biochemical tests can significantly improve patient management. Thus, our review clearly shows that several routine biochemical laboratory tests used in the case of certain types of cancer to solve specific diagnostic problems can help to determine the best clinical decisions for cancer patients.

\section{Acknowledgements}

The authors would like to thank Edward Jackson (NHS Mental Health Care, Great Yarmouth and Waveney, UK) for valuable comments on the manuscript.

\section{Conflict of interest}

The authors declare that they have no conflict of interest.

\section{References}

1. Torre LA, Siegel RL, Ward EM, Jemal A. Global cancer incidence and mortality rates and trends - An update. Cancer Epidemiol Biomarkers Prev 2016; 25(1): 16-27. https://doi.org/10.1158/1055-9965.EPI-150578. 
2. Aebisher D, Bartusik D, Tabarkiewicz J. Laser flow cytometry as a tool for the advancement of clinical medicine. Biomed Pharmacother 2017; 85: 434-443. https://doi.org/10.1016/i.biopha.2016.11.048.

3. Chinen LTD, Abdallah EA, Braun AC, Flores BCTCP, Corassa M, Sanches $\mathrm{SM}$, et al. Circulating tumour cells as cancer biomarkers in the clinic. Adv Exp Med Biol 2017; 994: 1-41. https://doi.org/10.1007/978-3-31955947-6 1.

4. Neoh KH, Hassan AA, Chen A, Sun Y, Liu P, Xu KF, et al. Rethinking liquid biopsy: Microfluidic assays for mobile tumour cells in human body fluids. Biomaterials 2018; 150: 112-124. https://doi.org/10.1016/j.biomaterials.2017.10.006.

5. Cheng J, Tang Q, Cao X, Burwinkel B. Cell-free circulating DNA integrity based on peripheral blood as a biomarker for diagnosis of cancer: $A$ systematic review. Cancer Epidemiol Biomarkers Prev 2017; 26(11): 1595-1602. https://doi.org/10.1158/1055-9965.EPI-17-0502.

6. Kappel A, Keller A. miRNA assays in the clinical laboratory: workflow, detection technologies and automation aspects. Clin Chem Lab Med 2017; 55(5): 636-647. https://doi.org/10.1515/cclm-2016-0467.

7. Nagpal $M$, Singh $S$, Singh $P$, Chauhan $P$, Zaidi MA. Tumour markers: A diagnostic tool. Natl J Maxillofac Surg 2016; 7(1): 17-20. https://doi.org/10.4103/0975-5950.196135.

8. Shukla HD. Comprehensive analysis of cancer-proteogenome to identify biomarkers for the early diagnosis and prognosis of cancer. $\begin{array}{lll}\text { Proteomes } & \text { 2017; } & \end{array}$ https://doi.org/10.3390/proteomes5040028.

9. Duffy MJ, Crown J. Companion biomarkers: paving the pathway to personalized treatment for cancer. Clin Chem 2013; 59(10): 1447-1456. https://doi.org/10.1373/clinchem.2012.200477.

10. Body JJ, Niepel D, Tonini G. Hypercalcaemia and hypocalcaemia: finding the balance. Support Care Cancer 2017; 25(5): 1639-1649. https://doi.org/10.1007/s00520-016-3543-1.

11. Mirrakhimov AE. Hypercalcaemia of malignancy: An update on pathogenesis and management. N Am J Med Sci 2015; 7(11): 483-493. https://doi.org/10.4103/1947-2714.170600.

12. Sternlicht $H$, Glezerman IG. Hypercalcaemia of malignancy and new treatment options. Ther Clin Risk Manag 2015; 11: 1779-1788. https://doi.org/10.2147/TCRM.S83681.

13. Gastanaga VM, Schwartzberg LS, Jain RK, Pirolli M, Quach D, Quigley $\mathrm{JM}$, et al. Prevalence of hypercalcaemia among cancer patients in the United States. Cancer Med 2016; 5(8): 2091-2100. https://doi.org/10.1002/cam4.749.

14. Lumachi F, Brunello A, Roma A, Basso U. Cancer-induced hypercalcaemia. Anticancer Res 2009; 29(5): 1551-1555. https://www.ncbi.nlm.nih.gov/pubmed/19443365.

15. Goldner W. Cancer-related hypercalcaemia. J Oncol Pract 2016; 12(5): 426-432. https://doi.org/10.1200/JOP.2016.011155.

16. Soyfoo MS, Brenner K, Paesmans M, Body JJ. Non-malignant causes of hypercalcaemia in cancer patients: a frequent and neglected occurrence. Support Care Cancer 2013; 21(5): 1415-1419. https://doi.org/10.1007/s00520-012-1683-5.

17. Reagan $\mathrm{P}$, Pani $\mathrm{A}$, Rosner $\mathrm{MH}$. Approach to diagnosis and treatment of hypercalcaemia in a patient with malignancy. Am J Kidney Dis 2014; 63(1): 141-147. https://doi.org/10.1053/i.ajkd.2013.06.025.

18. Kim YJ, Kim SH, Kim JW, Lee JO, Kim JH, Bang SM, et al. Gastric cancer with initial bone metastasis: a distinct group of diseases with poor prognosis. Eur J Cancer 2014; 50(16): 2810-2821. https://doi.org/10.1016/i.ejca.2014.08.003

19. Tanaka R, Yonemori K, Hirakawa A, Kinoshita F, Takahashi N, Hashimoto J, et al. Risk factors for developing skeletal-related events in breast cancer patients with bone metastases undergoing treatment with bone-modifying agents. Oncologist 2016; 21(4): 508-513. https://doi.org/10.1634/theoncologist.2015-0377.

20. Huang $P$, Lan $M$, Peng AF, Yu QF, Chen WZ, Liu ZL, et al. Serum calcium, alkaline phosphotase and hemoglobin as risk factors for bone metastases in bladder cancer. PLoS One 2017; 12(9): e0183835. https://doi.org/10.1371/journal.pone.0183835.

21. Penel N, Dewas S, Hoffman A, Adenis A. Cancer-associated hypercalcaemia: validation of a bedside prognostic score. Support Care Cancer 2009; 17(8): 1133-1135. https://doi.org/10.1007/s00520-0090607-5.

22. Le Tinier F, Vanhuyse M, Penel N, Dewas S, El-Bedoui S, Adenis A. Cancer-associated hypercalcaemia in squamous-cell malignancies: a survival and prognostic factor analysis. Int J Oral Maxillofac Surg 2011; 40(9): 938-942. https://doi.org/10.1016/i.ijom.2010.11.028.

23. Zhang SJ, Hu Y, Cao J, Qian HL, Jiao SC, Liu ZF, et al. Analysis on survival and prognostic factors for cancer patients with malignancy-associated hypercalcaemia. Asian Pac J Cancer Prev 2014; 14(11): 6715-6719. https://doi.org/10.7314/apjcp.2013.14.11.6715.

24. Li X, Bie Z, Zhang Z, Li Y, Hu X, Liu W, et al. Clinical analysis of 64 patients with lung-cancer-associated hypercalcaemia. J Cancer Res Ther 2015; 11 Suppl: C275-C279. https://doi.org/10.4103/09731482.170539.

25. Jaishuen A, Jimenez C, Sirisabya N, Li Y, Zheng $H, H u$ W, et al. Poor survival outcome with moderate and severe hypercalcaemia in gynecologic malignancy patients. Int J Gynecol Cancer 2009; 19(2): 178-185. https://doi.org/10.1111/IGC.0b013e31819c0fd0.

26. Jin J, Chung JO, Chung MY, Cho DH, Chung DJ. Clinical characteristics, causes and survival in 115 cancer patients with parathyroid hormone related protein-mediated hypercalcaemia. J Bone Metab 2017; 24(4): 249-255. https://doi.org/10.11005/jbm.2017.24.4.249.

27. Schattner A, Dubin I, Huber R, Gelber M. Hypocalcaemia of malignancy. Neth J Med 2016; 74(6): 231-239. https://pubmed.ncbi.nlm.nih.gov/27571720/.

28. Carroll B, Fleisher M, Pessin MS, Richardson S, Ramanathan LV. Pseudohypocalcaemia in cancer patients: A recommendation for the postanalytical correction of serum calcium in patients with hypoalbuminemia. Clin Chem 2017; 63(7): 1302-1304. https://doi.org/10.1373/clinchem.2017.272997.

29. Prince MR, Erel HE, Lent RW, Blumenfeld J, Kent KC, Bush HL, et al. Gadodiamide administration causes spurious hypocalcaemia. Radiology 2003; 227(3): 639-646. https://doi.org/10.1148/radiol.2273012007.

30. Moore CD, Newman RC, Caridi JG. Spurious hypocalcaemia after gadodiamide-enhanced magnetic resonance imaging: a case report and review of the literature. Rev Urol 2006; 8(3): 165-168. https://pubmed.ncbi.nlm.nih.gov/17043710/.

31. Kreutle V, Blum C, Meier C, Past M, Müller B, Schütz $P$, et al. Bisphosphonate induced hypocalcaemia - report of six cases and review of the literature. Swiss Med Wkly 2014; 144: w13979. https://doi.org/10.4414/smw.2014.13979.

32. Huynh AL, Baker ST, Stewardson AJ, Johnson DF. Denosumabassociated hypocalcaemia: incidence, severity and patient characteristics in a tertiary hospital setting. Pharmacoepidemiol Drug Saf 2016; 25(11): 1274-1278. https://doi.org/10.1002/pds.4045.

33. Fokkema MI, de Heide LJ, van Schelven WD, Hamdy NA. Severe hypocalcaemia associated with extensive osteoblastic metastases in a patient with prostate cancer. Neth J Med 2005; 63(1): 34-37. https://pubmed.ncbi.nlm.nih.gov/15719851/.

34. Rizzo C, Vella S, Cachia MJ. Refractory hypocalcaemia complicating metastatic prostatic carcinoma. BMJ Case Rep 2015; 2015: bcr2015210003. https://doi.org/10.1136/bcr-2015-210003.

35. Cheikhrouhou Abdelmoula L, Amira C, Chaabouni L, Kchir MM, Zouari R. Hyperphosphatemia in multiple myeloma. Joint Bone Spine 2003; 70(6): 541-542. https://doi.org/10.1016/s1297-319x(03)00161-1.

36. Jain A, Butani L. Severe hyperphosphatemia resulting from high-dose liposomal amphotericin in a child with leukemia. J Pediatr Hematol Oncol 2003; 25(4): 324-326. https://doi.org/10.1097/00043426200304000-00012. 
37. Sutherland SM, Hong DK, Balagtas J, Gutierrez K, Dvorak CC, Sarwal M. Liposomal amphotericin $B$ associated with severe hyperphosphatemia. Pediatr Infect Dis J 2008; 27(11): 77-79. https://doi.org/10.7314/apjcp.2013.14.11.6715.

38. Ye Z, Palazzo JP, Lin L, Lai Y, Guiles F, Myers RE, et al. Postoperative hyperphosphatemia significantly associates with adverse survival in colorectal cancer patients. J Gastroenterol Hepatol 2013; 28(9): 14691475. https://doi.org/10.1111/jgh.12237.

39. Koduri PR. Hyperphosphatemia and tumour lysis syndrome. Ann Hematol 2005; 84(10): 696. https://doi.org/10.1007/s00277-005-1073x.

40. Mika D, Ahmad S, Guruvayoorappan C. Tumour lysis syndrome: implications for cancer therapy. Asian Pac J Cancer Prev 2012; 13(8): 3555-3560. https://doi.org/10.7314/apjcp.2012.13.8.3555.

41. Sarno J. Prevention and management of tumour lysis syndrome in adults with malignancy. J Adv Pract Oncol 2013; 4(2): 101-106. https://pubmed.ncbi.nlm.nih.gov/25031988/.

42. Wilson FP, Berns JS. Tumour lysis syndrome: new challenges and recent advances. Adv Chronic Kidney Dis 2014; 21(1): 18-26. https://doi.org/10.1053/j.ackd.2013.07.001.

43. Cairo MS, Bishop M. Tumour lysis syndrome: new therapeutic strategies and classification. Br J Haematol 2004; 127(1): 3-11. https://doi.org/10.1111/j.1365-2141.2004.05094.x.

44. Darmon M, Vincent F, Camous L, Canet E, Bonmati C, Braun T, et al. Tumour lysis syndrome and acute kidney injury in high-risk haematology patients in the rasburicase era. A prospective multicentre study from the Groupe de Recherche en Réanimation Respiratoire et Onco-Hématologique. $\mathrm{Br} J$ Haematol 2013; 162(4): 489-497. https://doi.org/10.1111/bjh.12415.

45. Carella AM, Marinell T, Di Pumpo M, Ponziano E, Benvenuto A. Metabolic disorders in hematologic malignancies. Arch Med 2015; $7(5: 14)$ :

1-8.

https://www.archivesofmedicine.com/medicine/metabolic-disordersin-hematologic-malignancies-areview. php?aid=7048.

46. Tartaglia F, Minisola S, Sgueglia M, Blasi S, Brunelli D, Degli Effetti E, et al. Tumour-induced hypophosphatemic osteomalacia associated with tertiary hyperparathyroidism: a case report. G Chir 2006; 27(1-2): 9-13. https://www.ncbi.nlm.nih.gov/pubmed/16608626.

47. Tantisattamo E, Ng RC. Dual paraneoplastic syndromes: small cell lung carcinoma-related oncogenic osteomalacia, and syndrome of inappropriate antidiuretic hormone secretion: report of a case and review of the literature. Hawaii Med J 2011; 70(7): 139-143. https://pubmed.ncbi.nlm.nih.gov/21886301/.

48. Bhatt AA, Mathews SS, Kumari A, Paul TV. Tumour-induced osteomalacia. Hong Kong Med J 2014; 20(4): 350.e1-2. https://doi.org/10.12809/hkmi133981.

49. Dadoniene J, Miglinas M, Miltiniene D, Vajauskas D, Seinin D, Butenas $P$, et al. Tumour-induced osteomalacia: a literature review and a case report. World J Surg Oncol 2016; 14(1): 4. https://doi.org/10.1186/s12957-015-0763-7.

50. Kabadi UM. Osteomalacia associated with prostatic cancer and osteoblastic metastases. Urology 1983; 21(1): 65-67. https://doi.org/10.1016/0090-4295(83)90129-2.

51. McMurtry CT, Godschalk M, Malluche $\mathrm{HH}$, Geng Z, Adler RA. Oncogenic osteomalacia associated with metastatic prostate carcinoma: case report and review of the literature. J Am Geriatr Soc 1993; 41(9): 983-985. https://doi.org/10.1111/j.15325415.1993.tb06765.x.

52. Lim SC, Tan CE, Aw TC, Khoo D, Eng P, Ho SC, et al. A man with osteoblastic metastasis and hypocalcaemia. Singapore Med J 2000; 41(2): 74-76. https://pubmed.ncbi.nlm.nih.gov/11063207/.

53. Soyoral $Y$, Aslan M, Ebinc S, Dirik $Y$, Demir C. Life-threatening hypophosphatemia and/or phosphate depletion in a patient with acute lymphoblastic leukemia: a rare case report. Am J Emerg Med 2014; 32(11): 1437.e3-5. https://doi.org/10.1016/j.ajem.2014.04.011.
54. Bellini E, Pia A, Brizzi MP, Tampellini M, Torta M, Terzolo M, et al. Sorafenib may induce hypophosphatemia through a fibroblast growth factor-23 (FGF23)-independent mechanism. Ann Oncol 2011; 22(4): 988-990. https://doi.org/10.1093/annonc/mdr010.

55. Gilreath JA, Stenehjem DD, Rodgers GM. Diagnosis and treatment of cancer-related anemia. Am J Hematol 2014; 89(2): 203-212. https://doi.org/10.1002/ajh.23628.

56. Gaspar BL, Sharma P, Das R. Anemia in malignancies: pathogenetic and diagnostic considerations. Hematology 2015; 20(1): 18-25. https://doi.org/10.1179/1607845414Y.0000000161.

57. Wu XN, Su D, Wang L, Yu FL. Roles of the hepcidin-ferroportin axis and iron in cancer. Eur J Cancer Prev 2014; 23(2): 122-133. https://doi.org/10.1097/CEJ.0b013e3283627f14.

58. Busti F, Marchi G, Ugolini S, Castagna A, Girelli D. Anemia and iron deficiency in cancer patients: Role of iron replacement therapy. Pharmaceuticals (Basel) 2018; 11(4): 94. https://doi.org/10.3390/ph11040094.

59. Naoum FA. Iron deficiency in cancer patients. Rev Bras Hematol Hemoter 2016; 38(4): 325-330. https://doi.org/10.1016/j.bjhh.2016.05.009.

60. Tingting H, Di S, Xiaoping C, Xiaohong W, Dong H. High preoperative serum ferritin predicted poor prognosis in non-metastatic colorectal cancer. Saudi Med J 2017; 38(3): 268-275. https://doi.org/10.15537/smj.2017.3.16110.

61. Sawayama H, Iwatsuki M, Kuroda D, Toihata T, Uchihara T, Koga $Y$, et al. Total iron-binding capacity is a novel prognostic marker after curative gastrectomy for gastric cancer. Int J Clin Oncol 2018; 23(4): 671-680. https://doi.org/10.1007/s10147-018-1274-7.

62. Iglesias P, Díez JJ. Management of endocrine disease: a clinical update on tumour-induced hypoglycemia. Eur J Endocrinol 2014; 170(4): R147R157. https://doi.org/10.1530/EJE-13-1012.

63. Weiser MA, Cabanillas ME, Konopleva M, Thomas DA, Pierce SA, Escalante $C P$, et al. Relation between the duration of remission and hyperglycemia during induction chemotherapy for acute lymphocytic leukemia with a hyperfractionated cyclophosphamide, vincristine, doxorubicin, and dexamethasone/methotrexate-cytarabine regimen. Cancer 2004; 100(6): 1179-1185. https://doi.org/10.1002/cncr.20071.

64. Park SM, Lim MK, Shin SA, Yun YH. Impact of prediagnosis smoking, alcohol, obesity, and insulin resistance on survival in male cancer patients: National Health Insurance Corporation Study. J Clin Oncol 2006; 24(31): 5017-5024. https://doi.org/10.1200/JCO.2006.07.0243.

65. Ali NA, O'Brien JM Jr, Blum W, Byrd JC, Klisovic RB, Marcucci G, et al. Hyperglycemia in patients with acute myeloid leukemia is associated with increased hospital mortality. Cancer 2007; 110(1): 96-102. https://doi.org/10.1002/cncr.22777.

66. Lamkin DM, Spitz DR, Shahzad MM, Zimmerman B, Lenihan DJ, Degeest $\mathrm{K}$, et al. Glucose as a prognostic factor in ovarian carcinoma. Cancer 2009; 115(5): 1021-1027. https://doi.org/10.1002/cncr.24126.

67. Lee YY, Choi CH, Kim CJ, Song TJ, Kim MK, Kim TJ, et al. Glucose as a prognostic factor in non-diabetic women with locally advanced cervical cancer (IIB-IVA). Gynecol Oncol 2010; 116(3): 459-463. https://doi.org/10.1016/i.ygyno.2009.11.016.

68. Mirheydar HS, Banapour P, Massoudi R, Palazzi KL, Jabaji R, Reid EG, et al. What is the incidence of kidney stones after chemotherapy in patients with lymphoproliferative or myeloproliferative disorders? Int Braz J Urol 2014; 40(6): 772-780. https://doi.org/10.1590/S16775538.IBJU.2014.06.08.

69. Belay Y, Yirdaw K, Enawgaw B. Tumour lysis syndrome in patients with hematological malignancies. J Oncol 2017; 2017: 9684909. https://doi.org/10.1155/2017/9684909.

70. Mato AR, Riccio BE, Qin L, Heitjan DF, Carroll M, Loren A, et al. A predictive model for the detection of tumour lysis syndrome during AML induction therapy. Leuk Lymphoma 2006; 47(5): 877-883. https://doi.org/10.1080/10428190500404662. 
71. Montesinos P, Lorenzo I, Martín G, Sanz J, Pérez-Sirvent ML, Martínez $D$, et al. Tumour lysis syndrome in patients with acute myeloid leukemia: identification of risk factors and development of a predictive model. Haematologica 2008; 93(1): 67-74. https://doi.org/10.3324/haematol.11575.

72. Kim HJ, Kim JE, Jung JH, Kim ER, Hong SN, Chang DK, et al. Uric acid is a risk indicator for metabolic syndrome-related colorectal adenoma: results in a korean population receiving screening colonoscopy. Korean J Gastroenterol 2015; 66(4): 202-208. https://doi.org/10.4166/kjg.2015.66.4.202.

73. Selcukbiricik F, Kanbay M, Solak Y, Bilici A, Kanıtez M, Balık E, et al. Serum uric acid as a surrogate marker of favorable response to bevacizumab treatment in patients with metastatic colon cancer. Clin Transl Oncol 2016; 18(11): 1082-1087. https://doi.org/10.1007/s12094-016-1485-1.

74. Zhang $C$, Wang $H$, Ning $Z$, Xu L, Zhuang L, Wang $P$, et al. Serum liver enzymes serve as prognostic factors in patients with intrahepatic cholangiocarcinoma. Onco Targets Ther 2017; 10: 1441-1449. https://doi.org/10.2147/OTT.S124161.

75. Haas M, Heinemann V, Kullmann F, Laubender RP, Klose C, Bruns CJ, et al. Prognostic value of CA 19-9, CEA, CRP, LDH and bilirubin levels in locally advanced and metastatic pancreatic cancer: results from a multicenter, pooled analysis of patients receiving palliative chemotherapy. J Cancer Res Clin Oncol 2013; 139(4): 681-689. https://doi.org/10.1007/s00432-012-1371-3.

76. Liu X, Meng QH, Ye Y, Hildebrandt MA, Gu J, Wu X. Prognostic significance of pretreatment serum levels of albumin, LDH and total bilirubin in patients with non-metastatic breast cancer. Carcinogenesis 2015; 36(2): 243-248. https://doi.org/10.1093/carcin/bgu247.

77. Zucker SD, Horn PS, Sherman KE. Serum bilirubin levels in the U.S. population: gender effect and inverse correlation with colorectal cancer. Hepatology 2004; 40(4): 827-835. https://doi.org/10.1002/hep.20407.

78. Jirásková A, Novotný J, Novotný L, Vodicka P, Pardini B, Naccarati A, et al. Association of serum bilirubin and promoter variations in HMOX1 and UGT1A1 genes with sporadic colorectal cancer. Int J Cancer 2012; 131(7): 1549-1555. https://doi.org/10.1002/ijc.27412.

79. Peng YF, Goyal H, Xu GD. Serum bilirubin has an important role in multiple clinical applications. J Lab Precis Med 2017; 2(10): 82. https://doi.org/10.21037/jlpm.2017.09.08.

80. Gao C, Fang L, Li JT, Zhao HC. Significance and prognostic value of increased serum direct bilirubin level for lymph node metastasis in Chinese rectal cancer patients. World J Gastroenterol 2016; 22(8): 2576-2584. https://doi.org/10.3748/wig.v22.i8.2576.

81. Lee TH, Kim WR, Poterucha JJ. Evaluation of elevated liver enzymes. Clin Liver Dis 2012; 16(2): 183-198. https://doi.org/10.1016/i.cld.2012.03.006.

82. Tsai HJ, Hsieh MY, Tsai YC, Liu ZY, Hsieh HY, Lee CM, et al. Liver function tests may be useful tools for advanced cancer patient care: a preliminary single-center result. Kaohsiung J Med Sci 2014; 30(3): 146152. https://doi.org/10.1016/i.kjms.2013.09.005.

83. Buchet R, Millán JL, Magne D. Multisystemic functions of alkaline phosphatases. Methods Mol Biol 2013; 1053: 27-51. https://doi.org/10.1007/978-1-62703-562-0 3.

84. D'Oronzo S, Brown J, Coleman R. The role of biomarkers in the management of bone-homing malignancies. J Bone Oncol 2017; 9: 1-9. https://doi.org/10.1016/i.jbo.2017.09.001.

85. Du WX, Duan SF, Chen JJ, Huang JF, Yin LM, Tong PJ. Serum bonespecific alkaline phosphatase as a biomarker for osseous metastases in patients with malignant carcinomas: a systematic review and metaanalysis. J Cancer Res Ther 2014; 10 Suppl: C140-C143. https://doi.org/10.4103/0973-1482.145842.

86. Nozawa M, Hara I, Matsuyama H, Iki M, Nagao K, Nishioka T, et al. Significance of baseline bone markers on disease progression and survival in hormone-sensitive prostate cancer with bone metastasis.
World J Urol 2015; 33(9): 1263-1268. https://doi.org/10.1007/s00345014-1431-1.

87. Mountzios G, Ramfidis V, Terpos E, Syrigos KN. Prognostic significance of bone markers in patients with lung cancer metastatic to the skeleton: a review of published data. Clin Lung Cancer 2011; 12(6): 341-349. https://doi.org/10.1016/i.cllc.2011.03.032.

88. Kim SH, Shin KH, Moon SH, Jang J, Kim HS, Suh JS, et al. Reassessment of alkaline phosphatase as serum tumour marker with high specificity in osteosarcoma. Cancer Med 2017; 6(6): 1311-1322. https://doi.org/10.1002/cam4.1022.

89. Han J, Yong B, Luo C, Tan P, Peng T, Shen J. High serum alkaline phosphatase cooperating with MMP-9 predicts metastasis and poor prognosis in patients with primary osteosarcoma in Southern China. World J Surg Oncol 2012; 10: 37. https://doi.org/10.1186/1477-781910-37.

90. Milose JC, Filson CP, Weizer AZ, Hafez KS, Montgomery JS. Role of biochemical markers in testicular cancer: diagnosis, staging, and surveillance. Open Access J Urol 2011; 4: 1-8. https://doi.org/10.2147/OAJU.S15063.

91. Jung K, Lein M, Stephan C, Von Hösslin K, Semjonow A, Sinha P, et al. Comparison of 10 serum bone turnover markers in prostate carcinoma patients with bone metastatic spread: diagnostic and prognostic implications. Int J Cancer 2004; 111(5): 783-791. https://doi.org/10.1002/ijc.20314.

92. Wei RJ, Li TY, Yang XC, Jia N, Yang XL, Song HB. Serum levels of PSA, $A L P, I C T P$, and BSP in prostate cancer patients and the significance of ROC curve in the diagnosis of prostate cancer bone metastases. Genet Mol Res 2016; 15(2): gmr.15027707. https://doi.org/10.4238/gmr.15027707.

93. Chen XY, Lan M, Zhou Y, Chen WZ, Hu D, Liu JM, et al. Risk factors for bone metastasis from renal cell cancer. J Bone Oncol 2017; 9: 29-33. https://doi.org/10.1016/j.jbo.2017.10.004.

94. Li AA, Cao ZY, Liu JM, Huang SH, Liu ZL. The risk factors for bone metastases in patients with colorectal cancer. Medicine (Baltimore) 2018; 97(40): e12694. https://doi.org/10.1097/MD.0000000000012694.

95. Moslehi M, Cheki M, Salehi-Marzijarani $M$, Amuchastegui $T$, Gholamrezanezhad A. Predictors of bone metastasis in pre-treatment staging of asymptomatic treatment-naïve patients with prostate cancer. Rev Esp Med Nucl Imagen Mol 2013; 32(5): 286-289. https://doi.org/10.1016/j.remn.2013.01.002.

96. Ozu C, Nakashima J, Horiguchi Y, Oya M, Ohigashi T, Murai M. Prediction of bone metastases by combination of tartrate-resistant acid phosphatase, alkaline phosphatase and prostate specific antigen in patients with prostate cancer. Int J Urol 2008; 15(5): 419-422. https://doi.org/10.1111/j.1442-2042.2008.02029.x.

97. Ren HY, Sun LL, Li HY, Ye ZM. Prognostic significance of serum alkaline phosphatase level in osteosarcoma: A meta-analysis of published data. Biomed Res Int 2015; 2015: 160835. https://doi.org/10.1155/2015/160835.

98. Hou MF, Tsai LY, Tsai SM, Huang CJ, Huang YS, Hsieh JS, et al. Biochemical markers for assessment of bone metastases in patients with breast cancer. Kaohsiung J Med Sci 1999; 15(8): 452-460. https://pubmed.ncbi.nlm.nih.gov/10518361/.

99. Matsuyama H, Shimabukuro T, Hara I, Kohjimoto Y, Suzuki K, Koike H, et al. Combination of hemoglobin, alkaline phosphatase, and age predicts optimal docetaxel regimen for patients with castrationresistant prostate cancer. Int J Clin Oncol 2014; 19(5): 946-954. https://doi.org/10.1007/s10147-013-0638-2.

100.Han KS, Hong SJ. Serum alkaline phosphatase differentiates prostatespecific antigen flare from early disease progression after docetaxel chemotherapy in castration-resistant prostate cancer with bone metastasis. J Cancer Res Clin Oncol 2014; 140(10): 1769-1776. https://doi.org/10.1007/s00432-014-1710-7. 
101.Araujo CL, Vihko PT. Structure of acid phosphatases. Methods Mol Biol 2013; 1053: 155-166. https://doi.org/10.1007/978-1-62703-562-0 11.

102.Taira A, Merrick G, Wallner K, Dattoli M. Reviving the acid phosphatase test for prostate cancer. Oncology (Williston Park) 2007; 21(8): 10031010. https://pubmed.ncbi.nlm.nih.gov/17715699/.

103.Muniyan S, Chaturvedi NK, Dwyer JG, Lagrange CA, Chaney WG, Lin MF. Human prostatic acid phosphatase: structure, function and regulation. Int J Mol Sci 2013; 14(5): 10438-10464. https://doi.org/10.3390/ijms140510438.

104.Quintero IB, Araujo CL, Pulkka AE, Wirkkala RS, Herrala AM, Eskelinen EL, et al. Prostatic acid phosphatase is not a prostate specific target. Cancer Res 2007; 67(14): 6549-6554. https://doi.org/10.1158/00085472.CAN-07-1651.

105.Kirschenbaum A, Liu XH, Yao S, Leiter A, Levine AC. Prostatic acid phosphatase is expressed in human prostate cancer bone metastases and promotes osteoblast differentiation. Ann N Y Acad Sci 2011; 1237 : 64-70. https://doi.org/10.1111/j.1749-6632.2011.06198.x.

106.Larson SR, Chin J, Zhang X, Brown LG, Coleman IM, Lakely B, et al. Prostate cancer derived prostatic acid phosphatase promotes an osteoblastic response in the bone microenvironment. Clin Exp Metastasis 2014; 31(2): 247-256. https://doi.org/10.1007/s10585-0139625-2.

107.Janckila AJ, Yam LT. Biology and clinical significance of tartrateresistant acid phosphatases: new perspectives on an old enzyme. Calcif Tissue Int 2009; 85(6): 465-483. https://doi.org/10.1007/s00223009-9309-8.

108.Zenger S, He W, Ek-Rylander B, Vassiliou D, Wedin R, Bauer H, et al. Differential expression of tartrate-resistant acid phosphatase isoforms $5 \mathrm{a}$ and $5 \mathrm{~b}$ by tumour and stromal cells in human metastatic bone disease. Clin Exp Metastasis 2011; 28(1): 65-73. https://doi.org/10.1007/s10585-010-9358-4.

109.Patlaka C, Mira Pascual L, Paulie S, Henriksson AF, Arner $P$, Lång $P$, et al. The adipokine tartrate-resistant acid phosphatase $5 a$ in serum correlates to adipose tissue expansion in obesity. Biomarkers 2017; 22(8): 764-774. https://doi.org/10.1080/1354750X.2017.1334155.

110.Janckila AJ, Neustadt DH, Yam LT. Significance of serum TRACP in rheumatoid arthritis. J Bone Miner Res 2008; 23(8): 1287-1295. https://doi.org/10.1359/jbmr.080329.

111. Halleen JM, Tiitinen SL, Ylipahkala H, Fagerlund KM, Väänänen HK. Tartrate-resistant acid phosphatase $5 b$ (TRACP 5b) as a marker of bone resorption. Clin Lab 2006; 52(9-10): 499-509. https://pubmed.ncbi.nlm.nih.gov/17078477/.

112.Liu R, Cao J, Gao X, Zhang J, Wang L, Wang B, et al. Overall survival of cancer patients with serum lactate dehydrogenase greater than 1000 IU/L. Tumour Biol 2016; 37(10): 14083- 14088. https://doi.org/10.1007/s13277-016-5228-2.

113.de Wit S, Cleton FJ. Hypercalcaemia in patients with breast cancer: a survival study. J Cancer Res Clin Oncol 1994; 120(10): 610-614. https://doi.org/10.1007/bf01212816.

114.Petrelli F, Cabiddu M, Coinu A, Borgonovo K, Ghilardi M, Lonati V, et al. Prognostic role of lactate dehydrogenase in solid tumors: a systematic review and meta-analysis of 76 studies. Acta Oncol 2015; 54(7): 961970. https://doi.org/10.3109/0284186X.2015.1043026.

115.Seidemann K, Meyer U, Jansen P, Yakisan E, Rieske K, Führer M, et al. Impaired renal function and tumour lysis syndrome in pediatric patients with non-Hodgkin's lymphoma and B-ALL. Observations from the BFM-trials. Klin Padiatr 1998; 210(4): 279-284. https://doi.org/10.1055/s-2008-1043892.

116.Truong TH, Beyene J, Hitzler J, Abla O, Maloney AM, Weitzman S, et al. Features at presentation predict children with acute lymphoblastic leukemia at low risk for tumour lysis syndrome. Cancer 2007; 110(8): 1832-1839. https://doi.org/10.1002/cncr.22990.

117.Pang WW, Abdul-Rahman PS, Wan-Ibrahim WI, Hashim OH. Can the acute-phase reactant proteins be used as cancer biomarkers? Int J Biol
Markers 2010; 25(1):

$1-11$

https://doi.org/10.1177/172460081002500101.

118.Schrödl W, Büchler R, Wendler S, Reinhold P, Muckova P, Reindl J, et al. Acute phase proteins as promising biomarkers: Perspectives and limitations for human and veterinary medicine. Proteomics Clin Appl 2016; 10(11): 1077-1092. https://doi.org/10.1002/prca.201600028.

119.Pio R, Corrales L, Lambris JD. The role of complement in tumour growth. Adv Exp Med Biol 2014; 772: 229-262. https://doi.org/10.1007/978-1-4614-5915-6 11.

120.Kourtzelis I, Rafail S. The dual role of complement in cancer and its implication in anti-tumour therapy. Ann Transl Med 2016; 4(14): 265. https://doi.org/10.21037/atm.2016.06.26.

121.Afshar-Kharghan V. The role of the complement system in cancer. $J$ Clin Invest 2017; 127(3): 780-789. https://doi.org/10.1172/JCI90962.

122.Chang YK, Lai YH, Chu Y, Lee MC, Huang CY, Wu S. Haptoglobin is a serological biomarker for adenocarcinoma lung cancer by using the ProteomeLab PF2D combined with mass spectrometry. Am J Cancer Res 2016; 6(8): 1828-1836. https://www.ncbi.nlm.nih.gov/pubmed/27648369.

123.Lu J, Wang $Y$, Yan $M$, Feng $P$, Yuan $L$, Cai $Y$, et al. High serum haptoglobin level is associated with tumour progression and predicts poor prognosis in non-small cell lung cancer. Oncotarget 2016; 7(27): 41758-41766. https://doi.org/10.18632/oncotarget.9676.

124.Sun L, Hu S, Yu L, Guo C, Sun L, Yang Z, et al. Serum haptoglobin as a novel molecular biomarker predicting colorectal cancer hepatic metastasis. Int J Cancer 2016; 138(11): 2724-2731. https://doi.org/10.1002/ijc.29993.

125.El-Akawi ZJ, Abu-Awad AM, Khouri NA. Alpha-1 antitrypsin blood levels as indicator for the efficacy of cancer treatment. World J Oncol 2013; 4(2): 83-86. https://doi.org/10.4021/wjon663e.

126.Pérez-Holanda S, Blanco I, Menéndez M, Rodrigo L. Serum concentration of alpha-1 antitrypsin is significantly higher in colorectal cancer patients than in healthy controls. BMC Cancer 2014; 14: 355. https://doi.org/10.1186/1471-2407-14-355.

127.Skřivanová K, Anderková L, Brančíková D, Jarkovský J, Benešová K, Elfmarková $\mathrm{N}$, et al. Predicting vitality change in older breast cancer survivors after primary treatment - an approach based on using timerelated difference of pro-inflammatory marker C-reactive protein. Klin Onkol 2016; 29(1): 52-58. https://doi.org/10.14735/amko201652.

128.Ko YJ, Kwon YM, Kim KH, Choi HC, Chun SH, Yoon HJ, et al. Highsensitivity C-reactive protein levels and cancer mortality. Cancer Epidemiol Biomarkers Prev 2012; 21(11): 2076-2086. https://doi.org/10.1158/1055-9965.EPI-12-0611.

129.Nomura T, Huang WC, Zhau HE, Wu D, Xie Z, Mimata $H$, et al. $\beta 2$ microglobulin promotes the growth of human renal cell carcinoma through the activation of the protein kinase A, cyclic AMP-responsive element-binding protein, and vascular endothelial growth factor axis. Clin Cancer Res 2006; 12(24): 7294-7305. https://doi.org/10.1158/1078-0432.CCR-06-2060.

130.Jiang Q, Patima S, Ye DX, Pan HY, Zhang P, Zhang ZY. Upregulation of $\beta 2$-microglobulin expression in progressive human oral squamous cell carcinoma. Oncol Rep 2012; 27(4): 1058-1064. https://doi.org/10.3892/or.2011.1613.

131.Chen SS, Chen KK, Lin AT, Chang YH, Wu HH, Chang LS. Correlation between pretreatment serum biochemical markers and treatment outcome for prostatic cancer with bony metastasis. J Chin Med Assoc 2009; 72(6): 301-306. https://doi.org/10.1016/S1726-4901(09)703764 .

132.Nazha B, Moussaly E, Zaarour M, Weerasinghe C, Azab B. Hypoalbuminemia in colorectal cancer prognosis: Nutritional marker or inflammatory surrogate? World J Gastrointest Surg 2015; 7(12): 370-377. https://doi.org/10.4240/wjgs.v7.i12.370.

133.Ralston SH, Gallacher SJ, Patel U, Campbell J, Boyle IT. Cancerassociated hypercalcaemia: morbidity and mortality. Clinical 
experience in 126 treated patients. Ann Intern Med 1990; 112(7): 499504. https://doi.org/10.7326/0003-4819-112-7-499.

134.Ramos REO, Perez Mak M, Alves MFS, Piotto GHM, Takahashi TK, Gomes da Fonseca L, et al. Malignancy-related hypercalcaemia in advanced solid tumours: survival outcomes. J Glob Oncol 2017; 3(6): 728-733. https://doi.org/10.1200/JG0.2016.00890.

135.Lin TC, Liang KL, Lee LC, Hsu CY, Yen TT. Cancer-related hypercalcaemia in oral cancer. Int J Oral Maxillofac Surg 2018; 47(6): 685-691. https://doi.org/10.1016/i.ijom.2017.10.015.

136.Daumerie C, Maiter D, Gruson D. Serum calcitonin estimation in medullary thyroid cancer: basal or stimulated levels? Thyroid Res 2013; 6 Suppl 1(Suppl 1): S4. https://doi.org/10.1186/1756-6614-6-S1-S4.

137.Indrasena BS. Use of thyroglobulin as a tumour marker. World J Biol Chem 2017; 8(1): 81-85. https://doi.org/10.4331/wjbc.v8.i1.81.

138.Abdel-Baset HA, Eldin EN, Eltayeb AA, Hussein AM. Clinical and laboratory approach for the identification of the risk for tumour lysis syndrome in children with acute lymphoblastic leukemia. Life Sci J 2012; 9(1): 189-195. https://doi.org/10.7537/marslsj090112.27.

139.Bahoush GR, Yazdi E, Ansari SH, Arjmandi KH, Vossough P. Identification of children with acute lymphoblastic leukemia at low risk for tumour lysis syndrome. J Blood Disord Transfus 2015; 6(6): 318. https://doi.org/10.4172/2155-9864.1000318.

140.Alataş F, Alataş O, Metintaş M, Colak O, Erginel S, Harmanci E. Usefulness of bone markers for detection of bone metastases in lung cancer patients. Clin Biochem 2002; 35(4): 293-296. https://doi.org/10.1016/s0009-9120(02)00316-8.

141.Kang EJ, Lee SY, Kim HJ, Min KH, Hur GY, Shim JJ, et al. Prognostic factors and skeletal-related events in patients with small cell lung cancer with bone metastases at the time of diagnosis. Oncology 2016; 90(2): 103-111. https://doi.org/10.1159/000442949.

142.Zhou Y, Yu QF, Peng AF, Tong WL, Liu JM, Liu ZL. The risk factors of bone metastases in patients with lung cancer. Sci Rep 2017; 7(1): 8970. https://doi.org/10.1038/s41598-017-09650-y.

143.Donovan PJ, Achong N, Griffin K, Galligan J, Pretorius CJ, McLeod DS. PTHrP-mediated hypercalcaemia: causes and survival in 138 patients. $J$ Clin Endocrinol Metab 2015; 100(5): 2024-2029. https://doi.org/10.1210/jc.2014-4250.

144.Galindo RJ, Romao I, Valsamis A, Weinerman S, Harris YT. Hypercalcaemia of malignancy and colorectal cancer. World J Oncol 2016; 7(1): 5-12. https://doi.org/10.14740/wjon953w.

145. Major P, Lortholary A, Hon J, Abdi E, Mills G, Menssen HD, et al. Zoledronic acid is superior to pamidronate in the treatment of hypercalcaemia of malignancy: a pooled analysis of two randomized, controlled clinical trials. J Clin Oncol 2001; 19(2): 558-567. https://doi.org/10.1200/JCO.2001.19.2.558.

Authors:

Valery G. Zaitsev - PhD, Associate Professor, Department of Bioengineering and Bioinformatics, Volgograd State University, Volgograd, Russia. https://orcid.org/0000-0001-9191-2862.

Anastasia A. Zheltova - MD, PhD, Associate Professor, Department of Immunology and Allergology, Volgograd State Medical University, Volgograd, Russia. https://orcid.org/0000-0002-8078-6407.

Svetlana A. Martynova - MD, Head of Laboratory, Clinical Diagnostic Laboratory, Volgograd Regional Clinical Oncological Dispensary, Volgograd, Russia.

Elena V. Tibirkova - MD, PhD, Associate Professor, Department of Immunology and Allergology, Volgograd State Medical University, Volgograd, Russia. https://orcid.org/0000-0003-0972-5238. 
Appendix 1. Summary of clinical studies estimating the significance of routine blood serum/plasma clinical chemistry tests in cancer patient care.

\begin{tabular}{|c|c|c|c|c|c|}
\hline Disease / syndrome & Reference & $\begin{array}{c}\text { No. of } \\
\text { patients }\end{array}$ & $\begin{array}{c}\text { Type of } \\
\text { assessment }\end{array}$ & $\begin{array}{c}\text { Clinical chemistry Positive test values / } \\
\text { test } \\
\text { goal value }\end{array}$ & Outcome / results / recommendation \\
\hline General population & [128] & 33567 & Prognosis & $\geq 3 \mathrm{mg} / \mathrm{L}$ & $\begin{array}{c}\text { Predictor of cancer-related mortality in men, } \mathrm{HR}=1.25-2.07(95 \% \mathrm{Cl}) \\
\text { No influence on cancer-related mortality in women, } \mathrm{HR}=0.75-2.06(95 \% \mathrm{Cl})\end{array}$ \\
\hline $\begin{array}{l}\text { Acute lymphoblastic } \\
\text { eukaemia }\end{array}$ & [138] & 60 & Prognosis & $>1000 \mathrm{U} / \mathrm{L}$ & Predictor of TLS, OR = 1.2-20.9 $(95 \% \mathrm{Cl})$ \\
\hline $\begin{array}{l}\text { Acute lymphoblastic } \\
\text { leukaemia }\end{array}$ & [139] & 160 & Prognosis & $>2000 \mathrm{U} / \mathrm{L}$ & Predictor of TLS, OR = 1.52-9.89 $(95 \% \mathrm{Cl})$ \\
\hline $\begin{array}{l}\text { Acute lymphoblastic } \\
\text { leukaemia }\end{array}$ & [116] & 328 & Prognosis & $>2000 \mathrm{U} / \mathrm{L}$ & Predictor of TLS, OR = 4.0-14.7 $(95 \% \mathrm{Cl})$ \\
\hline $\begin{array}{l}\text { Acute lymphocytic } \\
\text { leukaemia }\end{array}$ & {$[63]$} & 278 & $\begin{array}{l}\text { Prognosis } \\
\text { Recurrence } \\
\text { monitoring }\end{array}$ & $\geq 11.1 \mathrm{mM}$ & $\begin{array}{l}\text { Predictor of shorter survival, } \mathrm{HR}=1.221-2.411(95 \% \mathrm{Cl}) \\
\text { Predictor of recurrence risk, } \mathrm{HR}=1.132-2.179(95 \% \mathrm{Cl})\end{array}$ \\
\hline $\begin{array}{l}\text { cute myeloid } \\
\text { eukaemia }\end{array}$ & {$[65]$} & 283 & Prognosis & $>6.1 \mathrm{mM}$ & Predictor of shorter survival, $\mathrm{HR}=1.23-1.55(95 \% \mathrm{Cl})$ \\
\hline $\begin{array}{l}\text { Acute myeloid } \\
\text { leukaemia }\end{array}$ & [70] & 194 & Prognosis & $>1.19 \times$ UNL & $\begin{array}{l}\text { Predictor of TLS, OR = } 7.26-403.65(95 \% \mathrm{CI}) \\
\text { Predictor of TLS, OR }=1.42-6.44(95 \% \mathrm{CI})\end{array}$ \\
\hline $\begin{array}{l}\text { Acute myeloid } \\
\text { leukaemia }\end{array}$ & [71] & 772 & Prognosis & $\begin{array}{l}>123.8 \mu \mathrm{M} \\
>446 \mu \mathrm{M} \\
1-4 \times \mathrm{UNL} \\
>4 \times \mathrm{UNL}\end{array}$ & $\begin{array}{l}\text { Predictor of clinical TLS, O } \\
\text { Predictor of clinical TLS, O } \\
\text { Predictor of clinical TLS, O } \\
\text { Predictor of clinical TLS, O }\end{array}$ \\
\hline $\begin{array}{l}\text { Non-Hodgkin's } \\
\text { lymphoma }\end{array}$ & {$[115]$} & 1192 & Prognosis & $>500$ & $\begin{array}{l}\text { High LHD activity and advanced stage of non-Hodgkin's lymphoma are } \\
\text { associated with a high risk of TLS development in pediatric patients }\end{array}$ \\
\hline $\begin{array}{l}\text { Breast cancer, non- } \\
\text { metastatic }\end{array}$ & {$[76]$} & 2425 & Prognosis & $\begin{array}{l}\text { Albumin } \\
\text { Protein, total } \\
\text { Bilirubin, total } \\
\text { ALP } \\
\text { ALT } \\
\text { AST } \\
\text { LDH }\end{array}$ & $\begin{array}{l}\text { Predictor of longer survival, } \mathrm{HR}=0.40-0.75(95 \% \mathrm{Cl}) \\
\text { No influence on survival, } \mathrm{HR}=0.57-1.81(95 \% \mathrm{Cl}) \\
\text { Predictor of longer survival, } \mathrm{HR}=0.45-0.85(95 \% \mathrm{Cl}) \\
\text { No influence on survival, } \mathrm{HR}=0.95-1.65(95 \% \mathrm{Cl}) \\
\text { No influence on survival, } \mathrm{HR}=0.59-1.04(95 \% \mathrm{Cl}) \\
\text { No influence on survival, } \mathrm{HR}=0.91-2.15(95 \% \mathrm{Cl}) \\
\text { Predictor of shorter survival, } \mathrm{HR}=1.08-1.88(95 \% \mathrm{Cl})\end{array}$ \\
\hline Breast cancer & [19] & 534 & Prognosis & $\begin{array}{l}\text { Calcium } \\
\text { LDH }\end{array}$ & $\begin{array}{l}\mathrm{CI}) \text { for the time to the } \\
\text { and frequency } \\
\text { and SRE frequency }\end{array}$ \\
\hline Lung cancer & {$[140]$} & 52 & $\begin{array}{l}\text { Diagnosis of } \\
\text { complications }\end{array}$ & oone-specific & 0.79 \\
\hline Lung cancer, small cell & {$[141]$} & 232 & Prognosis & $\geq 2 \times \cup N L$ & Predictor of shorter survival,, HR \\
\hline $\begin{array}{l}\text { Lung cancer, non- } \\
\text { small cell }\end{array}$ & {$[123]$} & 415 & Diagnosis & $\begin{array}{l}>1.495 \mathrm{~g} / \mathrm{L} \\
>1.495 \mathrm{~g} / \mathrm{L}\end{array}$ & $\begin{array}{l}\text { Sensitivity } 63.9 \% \text {, specificity } \\
\text { Predictor of shorter survive }\end{array}$ \\
\hline Lung cancer & & 1548 & Prognosis & not specified by & Predictor of shorter survival, $\mathrm{HR}=1.18-1.87(95 \% \mathrm{Cl})$ \\
\hline Lung cancer & [142] & 2021 & complications & authors & - \\
\hline Ovarian cancer & [66] & 199 & $\begin{array}{l}\text { Prognosis } \\
\text { Recurrence } \\
\text { monitoring }\end{array}$ & $\begin{array}{l}\text { per } 3.89 \mathrm{mM} \\
\text { per } 3.89 \mathrm{mM}\end{array}$ & $\begin{array}{l}\text { Predictor of shorter survival, } \mathrm{HR}=1.07-3.49(95 \% \mathrm{Cl}) \\
\text { Predictor of shorter remission interval, } \mathrm{HR}=1.42-4.28(95 \% \mathrm{Cl})\end{array}$ \\
\hline & & & Prognosis & $\geq 5.66 \mathrm{mM}$ & Predictor of shorter survival, $\mathrm{HR}=1.01-6.40(95 \% \mathrm{Cl})$ \\
\hline ncer & [67] & 134 & $\begin{array}{l}\text { Recurrence } \\
\text { monitoring }\end{array}$ & $\geq 5.66 \mathrm{mM}$ & Predictor of shorter progression-free interval, $\mathrm{HR}=1.06-3.33(95 \% \mathrm{Cl})$ \\
\hline Prostate cancer & [91] & 117 & $\begin{array}{l}\text { Prognosis } \\
\text { Diagnosis of } \\
\text { complications }\end{array}$ & $\begin{array}{l}\text { ALP, bone-specific } \\
\text { ALP, total } \\
\text { ALP, bone-specific }\end{array}$ & $\begin{array}{l}\text { No influence on survival, } \mathrm{RR}=0.10-41.0(95 \% \mathrm{Cl}) \\
\text { No influence on survival, RR }=0.01-20.8(95 \% \mathrm{Cl}) \\
\text { Diagnosis of bone metastases, sensitivity } 81 \% \text {, specificity } 93 \% \\
\text { Diagnosis of bone metastases, sensitivity } 75 \% \text {, specificity } 93 \%\end{array}$ \\
\hline ancer & [95] & 203 & $\begin{array}{l}\text { Diagnosis of } \\
\text { complications }\end{array}$ & \begin{tabular}{l}
$>286 \mathrm{U} / \mathrm{L}$ \\
\hdashline $2007 \pi^{2}$
\end{tabular} & 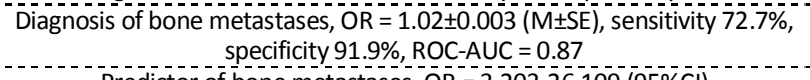 \\
\hline rostate cancer & [96] & 215 & Prognosis & $\begin{array}{l}>288 \mathrm{U} / \mathrm{L} \\
>10.4 \mathrm{U} / \mathrm{L}\end{array}$ & $\begin{array}{l}\text { Predictor of bone metastases, } \mathrm{OR}=3.203-26.109(95 \% \mathrm{Cl}) \\
\text { Predictor of bone metastases, OR }=1.009-8.287(95 \% \mathrm{Cl})\end{array}$ \\
\hline Prostate cancer & {$[92]$} & 83 & $\begin{array}{l}\text { Diagnosis of } \\
\text { complications }\end{array}$ & $>115 \mathrm{U} / \mathrm{L}$ & $\begin{array}{l}\text { Diagnosis of bone metastases, sensitivity } 57.14 \% \text {, specificity } 64.80 \%, \text { ROC- } \\
\text { AUC }=0.736\end{array}$ \\
\hline $\begin{array}{l}\text { Prostate cancer wit } \\
\text { pone metastases }\end{array}$ & [86] & 52 & Prognosis & ALP, bone-specific & Predictor of biochemical progressio \\
\hline $\begin{array}{l}\text { Prostate cancer, } \\
\text { treatment by } \\
\text { docetaxel }\end{array}$ & [99] & 279 & $\begin{array}{c}\text { Treatment } \\
\text { effectiveness } \\
\text { prediction }\end{array}$ & $\begin{array}{l}\geq 189 \mathrm{U} / \mathrm{L} \\
\geq 3.2 \mathrm{mg} / \mathrm{L} \\
\geq 215 \mathrm{U} / \mathrm{L} \\
\geq 189 \mathrm{U} / \mathrm{L} \\
\geq 3.2 \mathrm{mg} / \mathrm{L} \\
\geq 215 \mathrm{U} / \mathrm{L}\end{array}$ & $\begin{array}{l}\text { Predictor of shorter survival, } \mathrm{HR}=1.04-7.71(95 \% \mathrm{Cl}) \\
\text { Predictor of shorter survival, } \mathrm{HR}=1.08-3.55(95 \% \mathrm{Cl}) \\
\text { No influence on survival, } \mathrm{HR}=0.68-2.27(95 \% \mathrm{Cl}) \\
\text { Predictor of longer treatment, } \mathrm{HR}=0.12-0.54(95 \% \mathrm{Cl}) \\
\text { No influence on therapy duration, } \mathrm{HR}=0.35-1.90(95 \% \mathrm{Cl}) \\
\text { No influence on therapy duration, } \mathrm{HR}=0.31-1.18(95 \% \mathrm{Cl})\end{array}$ \\
\hline $\begin{array}{l}\text { Prostate cancer, } \\
\text { treatment by } \\
\text { docetaxel }\end{array}$ & [100] & 83 & Prognosis & $\begin{array}{l}\text { Initial decrease after } \\
\text { the treatment start }\end{array}$ & Predictor of transient PSA flare, OR $=1.648-161.558(95 \% \mathrm{Cl})$ \\
\hline Renal cancer & [93] & 372 & $\begin{array}{l}\text { Diagnosis of } \\
\text { complications }\end{array}$ & $>105.5 \mathrm{U} / \mathrm{L}$ & $\begin{array}{r}\text { Diagnosis of bone metastases, OR }=1.491-4.020(95 \% \mathrm{Cl}), \overline{R O C}-\bar{A} \bar{C} \mathrm{C}= \\
\text { sensitivity } 57.9 \% \text {, specificity } 83.5 \%\end{array}$ \\
\hline
\end{tabular}




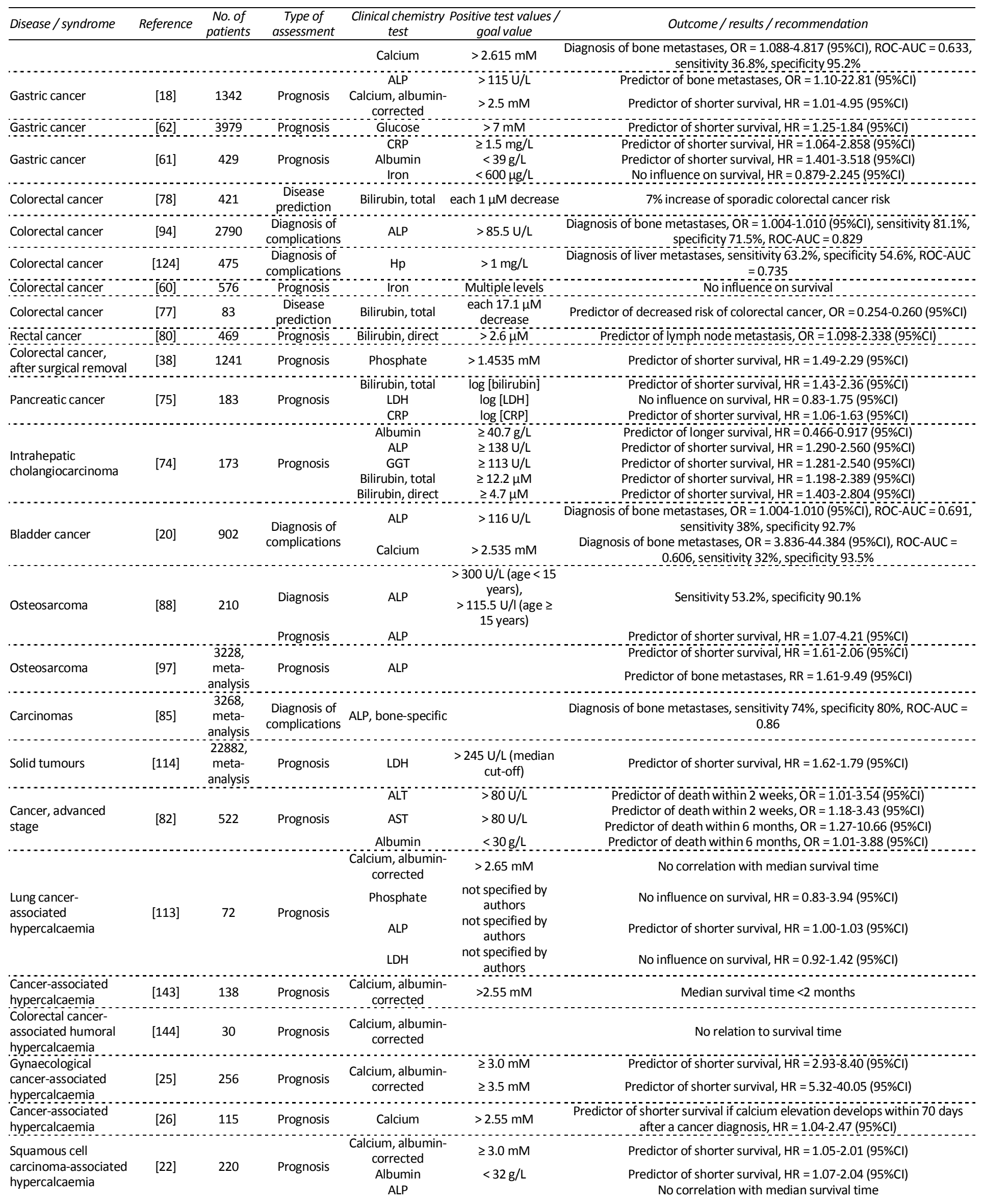




\begin{tabular}{|c|c|c|c|c|c|c|}
\hline Disease / syndrome & Reference & $\begin{array}{c}\text { No. of } \\
\text { patients }\end{array}$ & $\begin{array}{c}\text { Type of } \\
\text { assessment }\end{array}$ & $\begin{array}{l}\text { Clinical chemistry } P \\
\text { test }\end{array}$ & $\begin{array}{l}\text { Positive test values / } \\
\text { goal value }\end{array}$ & Outcome / results / recommendation \\
\hline \multirow{3}{*}{$\begin{array}{l}\text { Lung cancer- } \\
\text { associated } \\
\text { hypercalcaemia }\end{array}$} & \multirow{3}{*}{ [24] } & \multirow{3}{*}{64} & & $\begin{array}{l}\text { LDH } \\
\text { CRP } \\
\text { Urea }\end{array}$ & & \\
\hline & & & \multirow{2}{*}{ Prognosis } & $\begin{array}{l}\text { Calcium, albumin- } \\
\text { corrected }\end{array}$ & $\geq 2.90 \mathrm{mM}$ & $\begin{array}{l}\text { Median survival time was } 14 \text { days at higher levels vs. } 186 \text { days at lower } \\
\text { levels; } \mathrm{HR}=2.968-15.705(95 \% \mathrm{Cl})\end{array}$ \\
\hline & & & & ALP & $<120 \mathrm{U} / \mathrm{L}$ & $\begin{array}{l}\text { Median survival time was } 36 \text { days at lower levels vs. } 182 \text { days at higher } \\
\text { levels; } \mathrm{HR}=1.082-3.542(95 \% \mathrm{Cl})\end{array}$ \\
\hline \multirow{2}{*}{$\begin{array}{l}\text { Oral cancer-associated } \\
\text { hypercalcaemia }\end{array}$} & \multirow{2}{*}[135]{} & \multirow{2}{*}{91} & \multirow[b]{2}{*}{ Prognosis } & & & Positive correlation with median survival time $(r=0.31)$ \\
\hline & & & & $\begin{array}{l}\text { Calcium, albumin- } \\
\text { corrected }\end{array}$ & & No significant correlation with median survival time $(r=-0.09)$ \\
\hline $\begin{array}{l}\text { Severe cancer- } \\
\text { associated } \\
\text { hypercalcaemia }\end{array}$ & [145] & 287 & $\begin{array}{l}\text { Treatment } \\
\text { monitoring }\end{array}$ & $\begin{array}{l}\text { Calcium, albumin- } \\
\text { corrected }\end{array}$ & $2.70 \mathrm{mM}$ & Goal value during treatment by bisphosphonates \\
\hline \multirow[t]{2}{*}{$\begin{array}{l}\text { Cancer-associated } \\
\text { hypercalcaemia }\end{array}$} & \multirow[t]{2}{*}{ [21] } & \multirow[t]{2}{*}{252} & \multirow[t]{2}{*}{ Prognosis } & $\begin{array}{l}\text { Calcium, albumin- } \\
\text { corrected }\end{array}$ & $>2.83 \mathrm{mM}$ & $\begin{array}{l}\text { Median survival time of patients without squamous cell carcinoma or/and } \\
\text { liver metastasis was } 797 \text { days if both tests were negative and } 49 \text { days if at } \\
\text { least one of them was positive }\end{array}$ \\
\hline & & & & Albumin & $<34 \mathrm{~g} / \mathrm{L}$ & \\
\hline $\begin{array}{l}\text { Cancer-associated } \\
\text { hypercalcaemia }\end{array}$ & {$[133]$} & 126 & Prognosis & $\begin{array}{l}\text { Calcium } \\
\text { Albumin }\end{array}$ & & $\begin{array}{l}\text { Negative correlation with median survival time }(r=-0.39) \\
\text { Positive correlation with median survival time }(r=0.26)\end{array}$ \\
\hline \multirow{2}{*}{$\begin{array}{l}\text { Solid tumour cancer- } \\
\text { associated } \\
\text { hypercalcaemia }\end{array}$} & \multirow[b]{2}{*}{ [134] } & \multirow[b]{2}{*}{306} & \multirow[b]{2}{*}{ Prognosis } & Albumin & $<25 \mathrm{~g} / \mathrm{L}$ & No influence on survival, $\mathrm{HR}=0.82-2.05(95 \% \mathrm{Cl})$ \\
\hline & & & & CRP & $>30 \mathrm{mg} / \mathrm{L}$ & No influence on survival, $\mathrm{HR}=0.56-2.65(95 \% \mathrm{Cl})$ \\
\hline $\begin{array}{l}\text { Cancer-associated } \\
\text { hypercalcaemia }\end{array}$ & [23] & 115 & Prognosis & Calcium & $>2.75 \mathrm{mM}$ & $\begin{array}{l}\text { Duration of hypercalcaemia }>140 \text { days after a cancer diagnosis is a } \\
\text { predictor of shorter survival, } \mathrm{HR}=1.417-4.074(95 \% \mathrm{Cl})\end{array}$ \\
\hline $\begin{array}{l}\text { TLS during treatment } \\
\text { of haematological } \\
\text { cancer }\end{array}$ & [43] & $\begin{array}{l}\text { n.a. } \\
\text { (criteria of } \\
\text { TLS were } \\
\text { noted) }\end{array}$ & $\begin{array}{l}\text { Diagnosis / } \\
\text { Treatment } \\
\text { monitoring }\end{array}$ & Uric acid & $>476 \mu \mathrm{M}$ & $\begin{array}{l}\text { Laboratory TLS is diagnosed if } 2 \text { or more alterations are observed within } 7 \\
\text { days of chemotherapy }\end{array}$ \\
\hline
\end{tabular}

ALP, alkaline phosphatase; ALT, alanine aminotransferase; AST, aspartate aminotransferase; $\mathrm{Cl}$, confidence interval; CRP, C-reactive protein; $\mathrm{Hp}$, haptoglobin; HR, hazard ratio; IU, international units; $L D H$, lactate dehydrogenase; $\mathrm{M} \pm S E$, mean \pm standard error; n.a., not applicable; OR, odds ratio; PACP, prostatic acid phosphatase; ROC-AUC, area under the receiver operating characteristics (ROC) curve; SRE, skeletal-related event; TLS, tumour lysis syndrome; TRACP, tartrate-resistant acid phosphatase; UNL, upper normal limit. 